\title{
EFFECT OF DESIGN AND OPERATING PARAMETERS ON MEASURED AND PREDICTED PRESSURE DROP IN CYCLONE
}

\author{
Sabbah, F. M. , M. A. Abdel-Hadi ${ }^{* *}$, S. M. Radwan ${ }^{* *}$ and A. S. El-Sayed ${ }^{* *}$
}

\section{ABSTRACT}

In this study, many design parameters in cyclone such as cone height (30, 50 and $70 \mathrm{~cm})$, vortex finder length $(0,10,20,30$ and $40 \mathrm{~cm})$ and dipleg length (25, 40 and $55 \mathrm{~cm})$ were investigated under operating parameters via inlet air velocity $(14,16,18$ and $20 \mathrm{~m} / \mathrm{s})$ to find out the pressure drop $(\triangle P)$ of the cyclone empirically and predictively. The $\triangle P$ between inlet and outlet of the cyclone was measured experimentally by differential inclined manometer, while some mathematical models were used to predict $\triangle P$ of cyclone based on Shepherd and Lapple (1939), Barth (1956), Casal and Martinez-Benet (1983), Dirgo (1988) and Coker (1993). Some statistical indicators were used to compare and validate the measured with predicted results. As a result of this experiment, the maximum empirical $\Delta P$ were 161.3, 181.7 and 250.8 Pa recorded at inlet air velocity of $20 \mathrm{~m} / \mathrm{s}$, cone heights of 30,50 and $70 \mathrm{~cm}$ under vortex finder lengths of 40,40 and $0 \mathrm{~cm}$ and dipleg lengths of 55, 25 and $25 \mathrm{~cm}$, respectively. Meanwhile, the minimum $\Delta P$ were 60.2, 63,6 and $80.6 \mathrm{~Pa}$ recorded at inlet air velocity of $14 \mathrm{~m} / \mathrm{s}$, cone heights of 30,50 and $70 \mathrm{~cm}$ under vortex finder lengths of 10,30 and $40 \mathrm{~cm}$ and dipleg lengths of 25, 55 and $55 \mathrm{~cm}$, respectively. Furthermore, the best models to predict the pressure drop were Shepherd \& Lapple, Coker and Dirgo, respectively. The Shepherd \& Lapple model was more validation with cone heights of 50, 30 and $70 \mathrm{~cm}$, respectively. Meanwhile, the predicted model Coker was more validation with cone heights of 30,50 and $70 \mathrm{~cm}$, respectively. While, Dirgo model was more validation to experimental data at vortex finder length of $20 \mathrm{~cm}$ then 30 and $10 \mathrm{~cm}$, respectively.

Key words: Cyclone, Pressure drop, Inlet air velocity, Cone height, Vortex finder length, dipleg length.

\footnotetext{
* Ph.D. Student, Agric. Eng. Dept., Faculty of Agric., Suez Canal Univ.

** Prof., Agric. Eng. Dept., Faculty of Agric., Suez Canal Univ., 41522 Ismailia, Egypt.
} 


\section{NOMENCLATURE}

a : cyclone inlet height, $\mathrm{m}$.

A : cross-sectional areas of the inlet, $\mathrm{m}^{2}$.

b : cyclone inlet width, $m$.

$c_{o} \quad$ : mass ratio of dust feeding the cyclone to the gas flow rate, dimensionless.

D : cyclone vortex finder (exit pipe) diameter, $m$.

$\mathrm{D}_{\mathrm{b}} \quad$ : cyclone cone-tip or dust outlet or dipleg diameter, $\mathrm{m}$.

$\mathrm{D}_{\mathrm{c}} \quad$ : cyclone body (cylindrical part) diameter, $\mathrm{m}$.

$\mathrm{Eu}$ : Euler number, dimensionless.

$f \quad$ : friction factor $(f=0.05)$.

$\mathrm{g} \quad$ : gravity acceleration $9.81 \mathrm{~m} / \mathrm{sec}^{2}$.

$\mathrm{h}_{1} \quad$ : cyclone cylindrical part (body) height, $\mathrm{m}$.

$\mathrm{h}_{2} \quad$ : cyclone conical part height, $\mathrm{m}$.

$\mathrm{h}_{3} \quad$ : cyclone dust outlet (dipleg) length, $\mathrm{m}$.

$\mathrm{H}_{\mathrm{CS}}$ : height of the control surface extending from the bottom of the vortex finder to the cyclone bottom or core length, as shown in Fig. (3), m.

$\mathrm{H}_{\mathrm{t}} \quad$ : cyclone total height (total height), $\mathrm{m}$.

$\mathrm{H}_{v} \quad$ : inlet velocity heads, $\mathrm{m}$.

$\mathrm{k} \quad$ : cyclone pressure drop constant, dimensionless.

$\mathrm{K}$ : The vortex finder entrance factor $(\mathrm{K}=4.4)$.

$\mathrm{n} \quad$ : number of measurements (statistics).

$\mathrm{P}_{1} \quad$ : pressure at air inlet, Pascal.

$\mathrm{P}_{2} \quad$ : pressure at air outlet, Pascal.

$\mathrm{P}_{\mathrm{si}} \quad$ : static pressure at inlet, $\mathrm{N} / \mathrm{m}^{2}$.

$\mathrm{P}_{\mathrm{so}} \quad$ : static pressure in outlet, $\mathrm{N} / \mathrm{m}^{2}$.

Q : gas volume flow rate, $\mathrm{m}^{3} / \mathrm{h}$ or $\mathrm{m}^{3} / \mathrm{s}$.

$\mathrm{q} \quad$ : term in Stairmands pressure drop model.

$\mathrm{R}$ : cyclone radius $\left(\mathrm{D}_{\mathrm{c}} / 2\right), \mathrm{m}$.

$R_{\text {in }}$ : radial position of the center of the inlet for a slot inlet as shown in Fig (3), $m$.

$\mathrm{R}_{\mathrm{x}} \quad$ : radius of vortex finder $(\mathrm{D} / 2), \mathrm{m}$.

$\mathrm{S} \quad$ : cyclone vortex finder or gas outlet length, $\mathrm{m}$.

$v_{i} \quad$ : average air velocity at the cyclone inlet, $\mathrm{m} / \mathrm{sec}$.

$v_{x} \quad$ : mean axial velocity in the vortex.

$\mathrm{v}_{\theta \mathrm{cs}}$ : tangential velocity at the control surface CS.

$\mathrm{x}$ : experimental value.

$\mathrm{x}_{1}$ : distance movement of liquid (water) in above inclined tube, $\mathrm{m}$.

$\mathrm{x}_{2}$ : distance movement of liquid (water) in below inclined tube, $\mathrm{m}$.

y : predicted value.

$\mathrm{y}_{1}$ : vertical distance corresponding to $\mathrm{x} 1, \mathrm{~m}$.

$\mathrm{y}_{2} \quad$ : vertical distance corresponding to $\mathrm{x} 2, \mathrm{~m}$.

$\mathrm{Z}$ : pressure head (difference in water levels), $\mathrm{m}$.

$\alpha \quad$ : manometer inclined angle, degree.

$\Delta \mathrm{P} \quad$ : pressure drop in the cyclone, $\mathrm{N} / \mathrm{m}^{2}$.

$\Delta \mathrm{P}_{\text {body }}:$ loss the pressure in the cyclone body, $\mathrm{N} / \mathrm{m}^{2}$.

$\xi_{\mathrm{c}} \quad$ : pressure drop coefficient, dimensionless.

$\rho_{\mathrm{g}} \quad$ : gas density (air) $1.18, \mathrm{Kg} / \mathrm{m}^{3}$.

$\rho_{\mathrm{w}} \quad$ : density of water, $1000 \mathrm{~kg} / \mathrm{m}^{3}$.

$\varphi \quad$ : constant, dimensionless.

$\boldsymbol{\nabla}$ : reference level. 


\section{INTRODUCTION}

The cyclone is one of the most important air purifiers and
separation of solids from the air stream and most common in
many agricultural processing industries and post-harvest operations. It is simple to install, low manufacturing and maintenance costs, no moving parts and the ability to operate under difficult operating conditions such as high temperature and pressure. In spite of the simplicity of install, the prediction of pressure drop inside the cyclone is very complex due to the interaction between designs and operating parameters. A great number of research projects have been dedicated to investigation of these parameters for distinct cyclone shapes under various operating conditions (Hoffmann et al., 1992).

It is desirable to operate at the lowest flow rate possible for which the collection efficiency of the cyclone is acceptable in order to reduce operating costs of the cyclone, which are a function of both inlet velocity and pressure drop. Thereby, the optimal design and operating parameters will be evaluated based on collection efficiency and pressure drop (Faulkner and Shaw, 2006).

The pressure drop across the cyclone is directly related to the inlet air velocity required to operate a cyclone device. Schnell and Brown (2002) presented that, inlet air velocity is a prime factor affecting the pressure drop and hence the cyclone efficiency. Efficiency increases with an increase inlet velocity as centrifugal force increases, but this also increases the pressure drop which is not favorable. While, Chuah et al. (2003) concluded that pressure drop is a function of the square of inlet velocity, so too high a velocity will cause excessive pressure drop. On the other hand, too low a velocity would cause a low efficiency. A very high inlet velocity would decrease the collection efficiency because of increased turbulence and re-entrainment of particles. Generally, it was found that the optimum operating velocity was around $18 \mathrm{~m} / \mathrm{s}$. Furthermore, Abdel-Hadi (2014) reported that the optimum practicable cyclone inlet velocity was $18.5 \mathrm{~m} / \mathrm{s}$.

Demir et al. (2016) used the nine modifications of Stairmand HighEfficiency type cyclone (Stairmand HE) with various cylindrical and conical heights to investigate their effects on pressure drop and flow field 
within cyclones. The experimental results indicated that, the designer should be aware of that the body and conical heights have significant effects on cyclone pressure drop. For a body height of less than $1.5 \mathrm{D}_{\mathrm{c}}$ and a conical height of less than $2.5 \mathrm{D}_{\mathrm{c}}$, pressure drop is more sensitive to conical height. On the other hand, body height is more effective on pressure drop when conical height is less than $2.5 \mathrm{D}_{\mathrm{c}}$ and body height is greater than $1.5 \mathrm{D}_{\mathrm{c}}$. Therefore, increasing both body and conical heights together leads to reduced pressure drops with higher costs of construction. The pressure drop in a cyclone is the difference of static pressure between the inlet and outlet, which can be written as follows according to (Chen and Shi, 2007):

$\Delta \mathrm{P}=\mathrm{P}_{\mathrm{si}}-\mathrm{P}_{\text {so }}$

The static pressure at the inlet cross-section is uniformly distributed because there is no swirling motion. It can be easily measured with a pressure tapping on the wall. But the static pressure at the wall outlet is quite different from its cross- sectional average due to the strong swirling flow. The dynamic pressure stored in the swirling motion can be significant. The determination of the static pressure downstream of a cyclone, hence the pressure drop becomes more complicated and difficult. There are two steps to calculate of cyclone pressure drop. The first step is to calculate the pressure drop in the number of inlet velocity heads $\left(\mathrm{H}_{v}\right)$ then calculate the pressure drop (Shepherd \& Lapple, 1939 and Kanshio, 2015).

$H_{v}=k \frac{a b}{D}$

$\Delta \mathrm{P}=\mathrm{H}_{v} \rho_{\mathrm{g}} \frac{v_{i}^{2}}{2}$

The main objective of this study was to investigate the effect of cyclone design (cone height, cyclone total height, vortex finder length, dipleg length) and operating parameter (inlet air velocity) on the pressure drop to determine the appropriate design of the cyclone with inlet velocity. Moreover, to assess the predictive validity of some literature correlations in comparison with the measured pressure drop to the better use with the existing theories. 


\section{MATERIALS AND METHODS}

\section{Experimental Unit}

The experimental unit was fabricated from galvanized steel sheet of 1.5 $\mathrm{mm}$ thickness; cutting and welding were by laser technology. The dimension and specification of the experimental unit are tabulated in Table (1) and the overview of cyclone annexed to the inclined watermanometer for measuring experimental pressure drop shown in Fig. (1).

Table (1): Dimension and specification of the experimental unit.

\begin{tabular}{cllc}
\hline \hline Parameter & Description & Values & Unit \\
\hline \hline $\mathrm{D}_{\mathrm{c}}$ & Cyclone body diameter & 30 & $\mathrm{~cm}$ \\
$\mathrm{~h}_{1}$ & Cyclone cylindrical part height & 50 & $\mathrm{~cm}$ \\
$\mathrm{~b}$ & Cyclone inlet width & 7.2 & $\mathrm{~cm}$ \\
$\mathrm{a}$ & Cyclone inlet height & 7.2 & $\mathrm{~cm}$ \\
$\mathrm{D}$ & Vortex finder diameter & 9.2 & $\mathrm{~cm}$ \\
$\mathrm{D}_{\mathrm{b}}$ & Dipleg diameter & 7.7 & $\mathrm{~cm}$ \\
\hline \hline
\end{tabular}

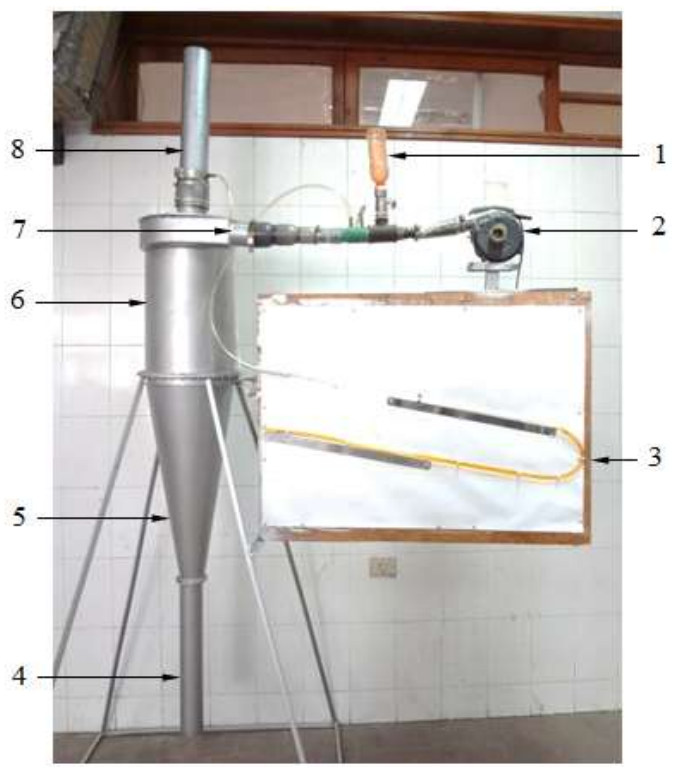

1 Set of input dust.

5 Cyclone conical part.

2 Air supply unit.

6 Cyclone cylindrical part.

3 Inclined differential manometer. 7 Cyclone air and dust inlet.

4 Dipleg (dust outlet).
8 Vortex finder (air outlet).

Fig. (1): The overview of cyclone annexed to the inclined water-manometer. 
Table (2) explains the parameters under study to determine the suitable cyclone design and inlet air velocity.

Table (2): The experimental parameters under study.

\begin{tabular}{cllc}
\hline \hline Parameter & Description & Values & Unit \\
\hline \hline $\mathrm{h}_{2}$ & Cyclone conical part height & 30,50 and 70 & $\mathrm{~cm}$ \\
$\mathrm{~h}_{3}$ & Dipleg length & 25,40 and 55 & $\mathrm{~cm}$ \\
$\mathrm{H}_{\mathrm{t}}$ & Cyclone total height & 80,100 and 120 & $\mathrm{~cm}$ \\
$\mathrm{~S}$ & Vortex finder length & $0,10,20,30$ and 40 & $\mathrm{~cm}$ \\
$v_{i}$ & Inlet air velocity & $14,16,18$ and 20 & $\mathrm{~m} / \mathrm{s}$ \\
\hline \hline
\end{tabular}

\section{Pressure Drop Measurements}

The cyclone static pressure drop $(\Delta \mathrm{P})$ is usually calculated as the pressure difference between the inlet and the pressure across the vortex finder exit (Hoekstra, 2000). To get the best accuracy (resolution) the differential inclined manometer was used for measurement the pressure drop. The differential inclined manometer made from the silicone tube internal and external diameter of 6.5 and $9.5 \mathrm{~mm}$, respectively, and filled with gage fluid (water). It was set at an angle $10^{\circ}(\alpha)$ to the horizontal and annexed between the air inlet and outlet (vortex finder) as shown as in Fig. (1 and 2).

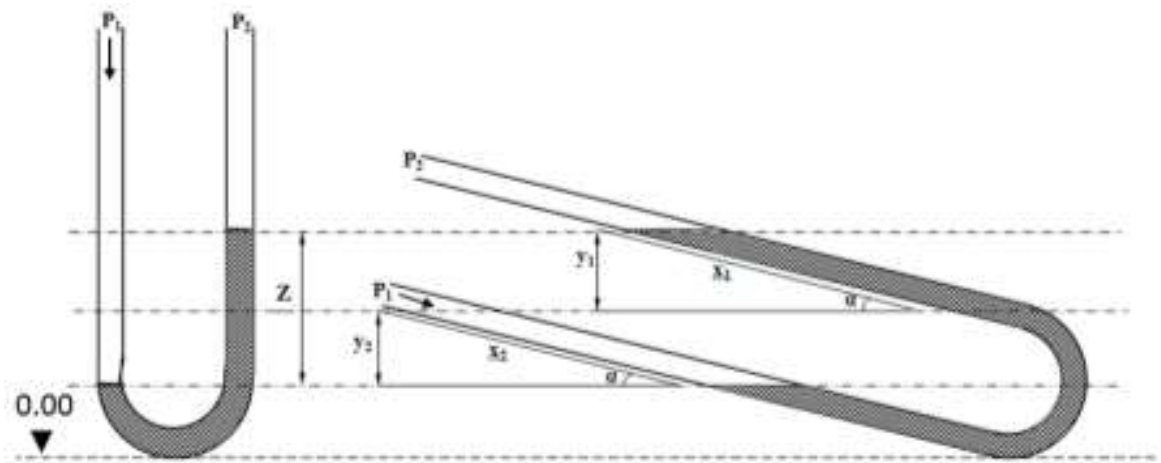

Fig. (2): The differential inclined manometer (Clifford et al., 2009).

The practically differential pressure (pressure drop, $\Delta \mathrm{P}$ ) between the inlet and outlet corresponding to a vertical difference of levels $\mathrm{y}_{1}$ and $\mathrm{y}_{2}$ gives move of the meniscus $\mathrm{x}_{1}$ and $\mathrm{x}_{2}$ along the slope. To calculate a vertical difference of levels $\mathrm{y}_{1}$ and $\mathrm{y}_{2}$ used the following equations according to (Clifford et al., 2009). 
$\mathrm{y}_{1}=\mathrm{x}_{1} \sin \alpha$

$\mathrm{y}_{2}=\mathrm{x}_{2} \sin \alpha$

$\mathrm{Z}=\mathrm{y}_{1}+\mathrm{y}_{2}$

$\Delta \mathrm{P}=\mathrm{P}_{1}-\mathrm{P}_{2}=\mathrm{Z} \times \mathrm{g} \times\left(\rho_{\mathrm{w}}-\rho_{\mathrm{g}}\right)$

Dewil et al. (2008) reported that, the static pressure drop $(\Delta \mathrm{P})$ between the gas inlet and outlet of a cyclone is proportional to the square of the flow rate $(\mathrm{Q})$, with a proportionality resistance coefficient $\left(\xi_{\mathrm{c}}\right)$ defined on the basis of the inlet velocity $\left(v_{i}=\mathrm{Q} / \mathrm{ab}\right)$, thus:

$\Delta \mathrm{P}=\xi_{\mathrm{c}} \frac{\rho_{\mathrm{g}} v_{i}^{2}}{2}$

Table (3) summarized the models equations which descripted the inlet velocity heads $\left(\mathrm{H}_{v}\right)$ or pressure drop coefficient $\left(\xi_{\mathrm{c}}\right)$ of empirical and theoretical models according to (Cortés and Gil, 2007).

Table (3): The pressure drop coefficient $\left(\xi_{c}\right)$ models according to (Cortés and Gil, 2007).

\begin{tabular}{|c|c|c|}
\hline Reference & Equation & Remarks \\
\hline \multicolumn{3}{|c|}{ Empirical models } \\
\hline $\begin{array}{l}\text { Shepherd \& } \\
\text { Lapple (1939) }\end{array}$ & $\xi_{\mathrm{c}}=\mathrm{Eu}=\left(\frac{16 \mathrm{~A}}{\mathrm{D}^{2}}\right)$ & (9) \\
\hline Coker (1993) & $\xi_{\mathrm{c}}=\mathrm{Eu}=9.47\left(\frac{\mathrm{A}}{\mathrm{D}^{2}}\right)$ & (10) \\
\hline $\begin{array}{l}\text { Casal and } \\
\text { Martinez-Benet } \\
\text { (1983) }\end{array}$ & $\xi_{\mathrm{c}}=\mathrm{Eu}=11.3\left(\frac{\mathrm{A}}{\mathrm{D}^{2}}\right)^{2}+3.33$ & (11) \\
\hline \multicolumn{3}{|c|}{ Theoretical model } \\
\hline Dirgo (1988) & $\xi_{c}=E u=20\left(\frac{A}{D^{2}}\right)\left(\frac{S / D_{c}}{\left(H_{t} / D_{c}\right)\left(h_{1} / D_{c}\right)\left(D_{b} / D_{c}\right)}\right)$ & (12) \\
\hline
\end{tabular}

Barth (1956) suggested another theoretical model of $\left(\xi_{c}\right)$ based on the equilibrium-orbit model and divided the pressure drop in the cyclone into three consists:

1- Loss the pressure at the inlet (this loss could be avoided by good design).

2- Loss the pressure in the cyclone body $\left(\Delta \mathrm{P}_{\text {body }}\right)$, it can be estimated as the following: 
$\Delta \mathrm{P}_{\text {body }}=\frac{\rho_{\mathrm{g}} v_{x}^{2} \mathrm{D}}{2 \mathrm{D}_{\mathrm{c}}}\left[\frac{1}{\left(\frac{v_{x}}{v_{\theta c s}}-\frac{\mathrm{H}_{\mathrm{t}}-\mathrm{S}}{0.5 \mathrm{D}} f\right)^{2}}-\left(\frac{v_{\theta c \mathrm{~s}}}{\mathrm{v}_{\mathrm{x}}}\right)^{2}\right]$

Where:

$$
\begin{aligned}
& v_{x}=\frac{Q}{\pi R_{x}^{2}} \\
& v_{\theta c s}=\frac{\pi R_{i n} R_{x} v_{x}}{a b \varphi+H_{c s} \pi f R_{i n}} \\
& R_{\text {in }}=R-\frac{b}{2} \\
& R_{x}=\frac{D}{2} \\
& \varphi=1-0.4\left(\frac{b}{R}\right)^{0.5}
\end{aligned}
$$

3- Loss the pressure in the vortex finder $\left(\Delta \mathrm{P}_{\mathrm{x}}\right)$, can be estimated using a semi- empirical approach as following:

$\Delta \mathrm{P}_{\mathrm{x}}=\left[0.5 \rho_{\mathrm{g}} v_{x}^{2}\right]\left[\left(\frac{v_{\theta \mathrm{cs}}}{v_{x}}\right)^{2}+\mathrm{K}\left(\frac{v_{\theta \mathrm{cs}}}{v_{x}}\right)^{\frac{4}{3}}\right]$

Therefore the total pressure drop is calculated as:

$\Delta \mathrm{P}=\Delta \mathrm{P}_{\text {body }}+\Delta \mathrm{P}_{\mathrm{x}}$

Hoffmann \& Stein (2008) explained the item the height of control surface $\left(\mathrm{H}_{\mathrm{cs}}\right)$ according to the equilibrium-orbit theory in the following Fig. (3)

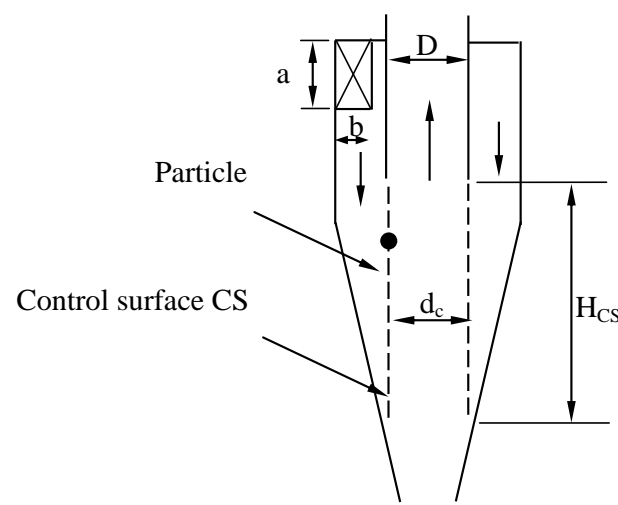

A

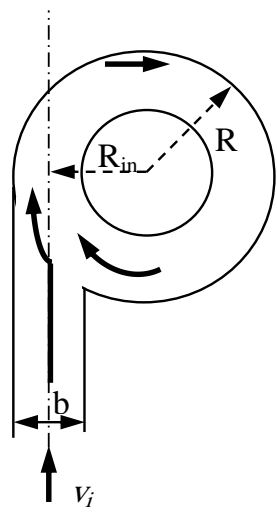

$\mathrm{B}$

Fig. (3): A- The control surface concept in the equilibrium-orbit model and B- the inlet flow pattern for tangential inlet cyclone (B) according to (Hoffmann and Stein, 2008). 


\section{Statistical indicators for empirical models}

The models validation parameters were used to assess the measured data of pressure drop in comparison with predictive validity of some literature correlations to put the data into better use with the existing theories. Four general statistical indicators for empirical models were chosen to evaluate the prediction ability of the pressure drop predicted models. These indicators are mean relative deviation (MRD, \%), a relative standard error of prediction (RSEP, \%), root mean square error (RMSE) and Pearson correlation coefficient (r), respectively.

- Mean relative deviation (MRD, \%) (Chen and Morey, 1989).

$\operatorname{MRD}(\%)=\left[\sum_{\mathrm{j}=1}^{\mathrm{n}} \frac{|\mathrm{x}-\mathrm{y}|}{\mathrm{x}}\right] \times \frac{100}{\mathrm{n}}$

The mean relative deviation modulus (MRD, \%) is widely adopted throughout the literature with a minimum value indicative of a good fit for predicting models (Van den Berg et al., 1981).

- Relative standard error of prediction (RSEP, \%) (Ghasemi and Niazi, 2005).

$\operatorname{RSEP}(\%)=100 \times \sqrt{\frac{\sum_{\mathrm{j}=1}^{\mathrm{n}}(\mathrm{x}-\mathrm{y})^{2}}{\sum_{\mathrm{j}=1}^{\mathrm{n}} \mathrm{x}^{2}}}$

Model accuracy is considered excellent when (RSEP) $<10 \%$, good if 10 $\%<($ RSEP $)<20 \%$, fair if $20 \%<($ RSEP $)<30 \%$ and poor if $($ RSEP $)>$ $30 \%$ (Li et al., 2013).

- Root mean square error (RMSE) (Jachner et al., 2007).

RMSE $=\sqrt{\frac{\sum_{j=1}^{\mathrm{n}}\left(\mathrm{x}_{\mathrm{j}}-\mathrm{y}_{\mathrm{j}}\right)^{2}}{\mathrm{n}}}$

- Pearson correlation coefficient (r) according to (Spatz, 2008).

$\mathrm{r}=\frac{\mathrm{n}\left(\sum \mathrm{xy}\right)-\left(\sum \mathrm{x}\right)\left(\sum \mathrm{y}\right)}{\sqrt{\mathrm{n} \sum \mathrm{x}^{2}-\left(\sum \mathrm{x}\right)^{2}} \sqrt{\mathrm{n} \sum \mathrm{y}^{2}-\left(\sum \mathrm{y}\right)^{2}}}$

In general, maximum value of the Pearson correlation coefficient (r) is indicating a better fit of the predicted model. In other hand the minimum values of mean relative deviation (MRD, \%), a relative standard error of prediction (RSEP, \%) and root mean square error (RMSE) selected as a best fit model (Tantar et al., 2014). 


\section{RESULTS AND DISCUSSION}

\section{Measured Pressure Drop}

In general, in obtaining results the experimental $\Delta \mathrm{P}$ increase with increase inlet air velocity and cone height and the results were agree with (Chuah et al., 2006 and Juengcharoensukying et al., 2017). Fig. (4) illustrated the relationship between inlet air velocity and pressure drop under the different cone heights, vortex finder lengths and dipleg lengths.

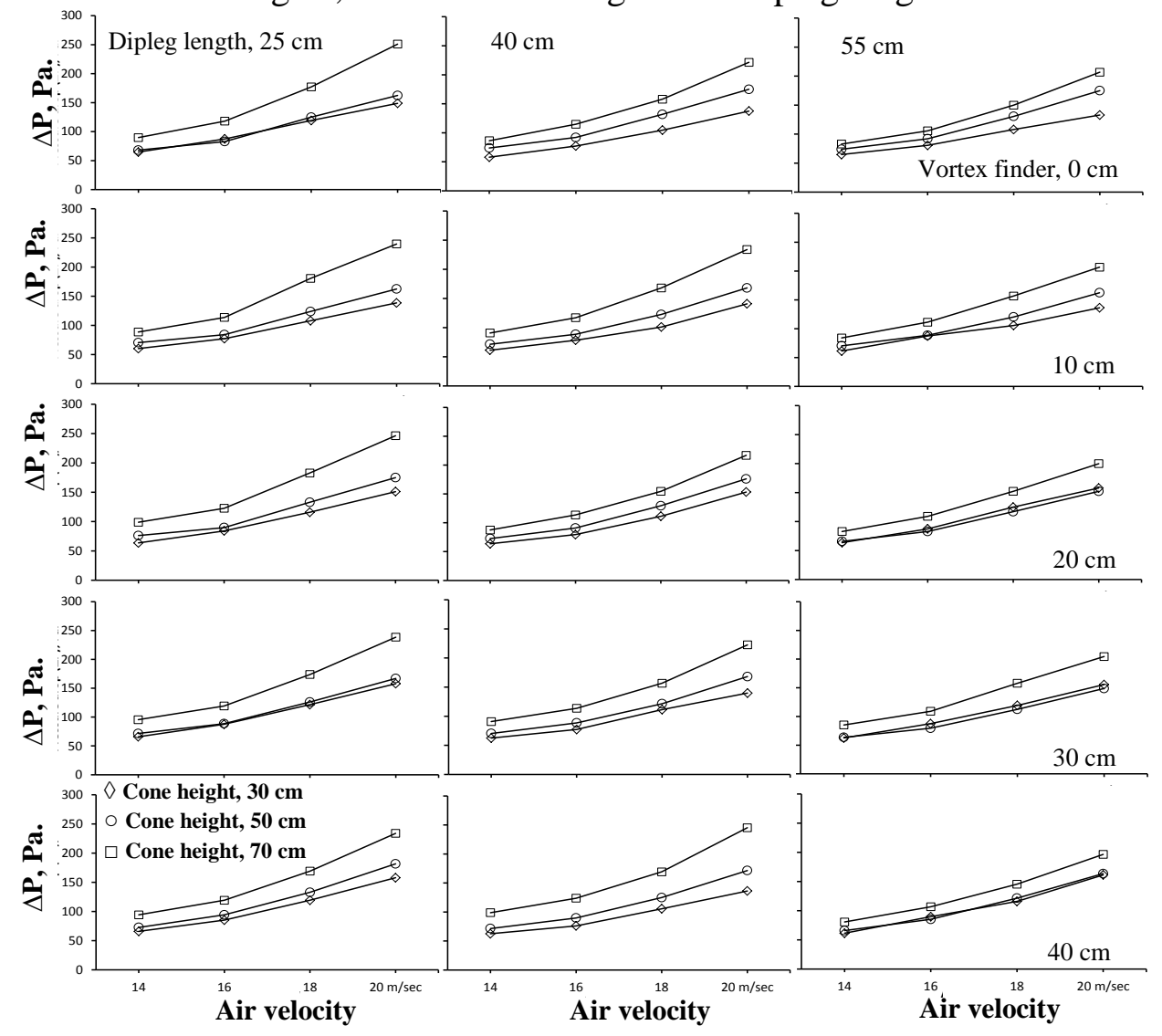

Fig. (4): Effect of inlet air velocity on measured pressure drop at different cone heights, vortex finder lengths and dipleg lengths.

The maximum $\Delta \mathrm{P}$ were $161.3,181.7$ and $250.8 \mathrm{~Pa}$ recorded at inlet air velocity of $20 \mathrm{~m} / \mathrm{s}$, cone heights of 30,50 and $70 \mathrm{~cm}$ under vortex finder lengths of 40, 40 and $0 \mathrm{~cm}$ and dipleg lengths of 55, 25 and $25 \mathrm{~cm}$, respectively. Meanwhile, the minimum $\Delta \mathrm{P}$ were $60.2,63,6$ and $80.6 \mathrm{~Pa}$ 
recorded at inlet air velocity of $14 \mathrm{~m} / \mathrm{s}$, cone heights of 30,50 and $70 \mathrm{~cm}$ under vortex finder lengths of 10,30 and $40 \mathrm{~cm}$ and dipleg lengths of 25 , 55 and $55 \mathrm{~cm}$, respectively. The results showed that the pressure drop was increased with increasing the cyclone size according to (Azadi et al., 2010). Also the observed results showed that, the effect of both vortex finder length and dipleg length on $\Delta \mathrm{P}$ was tiny effect and neglected, these results agree with (Elsayed, 2011).

\section{Predicted Pressure Drop}

The accurate prediction of cyclone $\Delta \mathrm{P}$ is very important because it relates directly to operating costs and overall collection efficiency. The most widely used models for the pressure drop coefficient $\left(\xi_{\mathrm{c}}\right)$ are Shepherd \& Lapple (1939); Barth (1956); Casal \& Martinez-Benet (1983); Dirgo (1988) and Coker (1993). These five theories above-mentioned were applied in equation (8) to predict the $\Delta \mathrm{P}$ according to (Dewil $\boldsymbol{e t}$ al., 2008) and validate them to the experimentally $\Delta \mathrm{P}$, which measured by the inclined differential manometer. Table (4) showed some statistical indicators to validate predicted with measured values of $\Delta \mathrm{P}$.

Table (4): Some statistical indicators to validate predicted with measured values of pressure drop.

\begin{tabular}{lcccccc}
\hline \hline $\begin{array}{l}\text { Statistics } \\
\text { parameters }\end{array}$ & Experiment & $\begin{array}{c}\text { Shepherd } \\
\text { \& Lapple }\end{array}$ & Coker & Dirgo & Barth & $\begin{array}{c}\text { Casal \& } \\
\text { Martinez }\end{array}$ \\
\hline \hline Mean & 120.6 & 117.9 & 69.8 & 96.6 & 625.8 & 404.5 \\
Std. deviation & 46.4 & 30.6 & 18.1 & 59.3 & 162.5 & 105.0 \\
R & - & $\mathbf{0 . 8 6 2 6 0}$ & 0.86260 & 0.33538 & 0.86151 & 0.86259 \\
MRD, \% & - & $\mathbf{1 5 . 4}$ & 39.1 & 39.0 & 446.1 & 252.9 \\
RSEP, \% & - & $\mathbf{1 9 . 6}$ & 46.5 & 51.2 & 402.8 & 226.2 \\
RMSE & - & $\mathbf{2 5 . 4}$ & 60.1 & 66.2 & 520.3 & 292.1 \\
\hline \hline
\end{tabular}

The Barth and Casal \& Martinez-Benet models were given an extreme result comparing with measured $\Delta \mathrm{P}$ because it has lower values of the Pearson correlation coefficient ( $\mathrm{r}$ ) and at the same time has the highest values of (MRD, \%), (RSEP, \%) and (RMSE) as shown in Table (4) according to (Tantar et al., 2014).

As shown in Table (4) bold values refer to the more accurately model Shepherd \& Lapple regarding particular indicator then Coker and Dirgo, respectively. The Shepherd \& Lapple model has the highest value of (r) 0.86260 and the lowest value of MRD \%, RSEP and RMSE, 
which were 15.4, 19.6 and 25.4, respectively. Figures (5, 6 and 7) illustrate the comparison between the best three models and the experimental results.
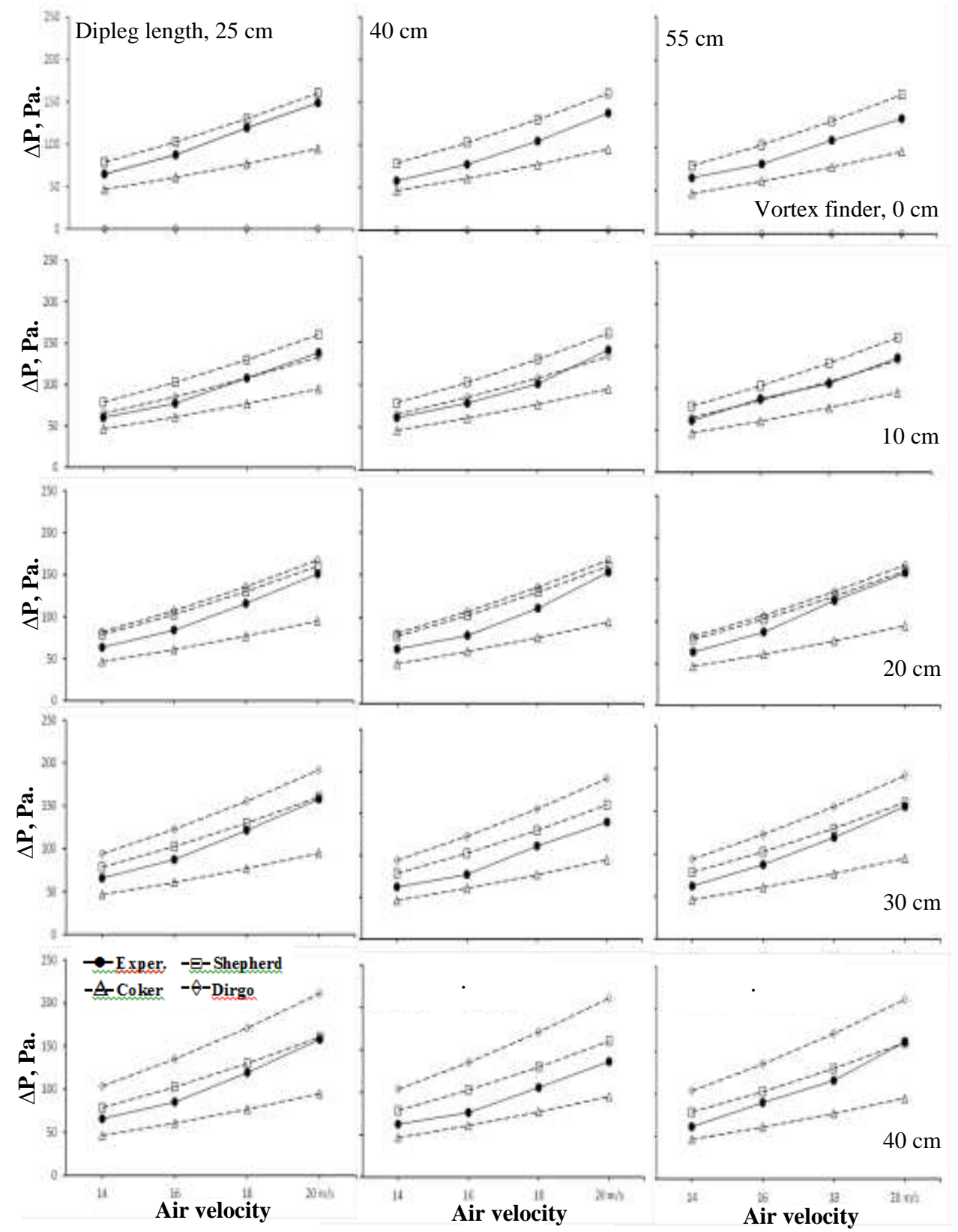

Fig. (5): The measured and predicted pressure drop at different coefficient models $\left(\xi_{c}\right)$ under the cone height of $30 \mathrm{~cm}$ at different dipleg lengths and vortex finder lengths. 
In general the $\Delta \mathrm{P}$ of cyclone under cone heights of 30,50 and $70 \mathrm{~cm}$ were increased with increasing the inlet air velocity. In Fig. (5) the measured values were closer to the Shepherd \& Lapple model while, the Dirgo model was equal zero Pascal at vortex finder length zero $\mathrm{cm}$ because the model including the effect of vortex finder length. Meanwhile, increasing the vortex finder length lead to the increasing the predicted values of Dirgo model corresponding on measured $\Delta \mathrm{P}$ at vortex finder length of 10 $\mathrm{cm}$ and corresponding on Shepherd \& Lapple model at vortex finder length of $20 \mathrm{~cm}$ then rise above both measured $\Delta \mathrm{P}$ and Shepherd $\boldsymbol{\&}$ Lapple model under vortex finder lengths of 30 and $40 \mathrm{~cm}$.

Fig. (6) illustrate the $\Delta \mathrm{P}$ of cyclone under cone height of $50 \mathrm{~cm}$. The experimental measured values were closer to the Shepherd \& Lapple model especially at inlet air velocity of $18 \mathrm{~m} / \mathrm{s}$. While, the Dirgo model was equal zero Pascal at vortex finder length of zero $\mathrm{cm}$ and corresponding on Shepherd \& Lapple model at vortex finder length of $20 \mathrm{~cm}$. Generally, the predicted value of Dirgo model increasing with increase the vortex finder length.

Fig. (7) presented the $\Delta \mathrm{P}$ of the cyclone under the cone height $70 \mathrm{~cm}$. The experimental measured values were higher than the predicted values of all models and it was closer to Shepherd \& Lapple model at inlet air velocities of 14 and $16 \mathrm{~m} / \mathrm{s}$ after that, by increasing inlet air velocity from 16 to $20 \mathrm{~m} / \mathrm{s}$ increasing the gap between the measured and predicted values. The values of Shepherd \& Lapple model were closer to Dirgo model at vortex finder lengths of 20 and $30 \mathrm{~cm}$ at all inlet air velocity.

To assess the effect of cone height on $\Delta \mathrm{P}$ and put the data into better use; the data were validated with predicted $\Delta \mathrm{P}$ models. Table (5 and 6) focused the comparison between the best predicted of $\Delta \mathrm{P}$ models and experiment results under different cone heights and dipleg length, respectively.

Table (5) presented the correlation between the best predicted models and experimental $\Delta \mathrm{P}$ under the cone heights of 30,50 and $70 \mathrm{~cm}$; the statistical values seem that the Shepherd \& Lapple model was more validation comparing with other models. At the same time, this model was more validation with cone heights of 50,30 and $70 \mathrm{~cm}$, respectively. Meanwhile, the predicted model Coker was more validation with cone 
heights of 30,50 and $70 \mathrm{~cm}$, respectively, due to the high value of (r) and lowest value of (MRD, \%), (RSEP, \%) and (RMSE), respectively.
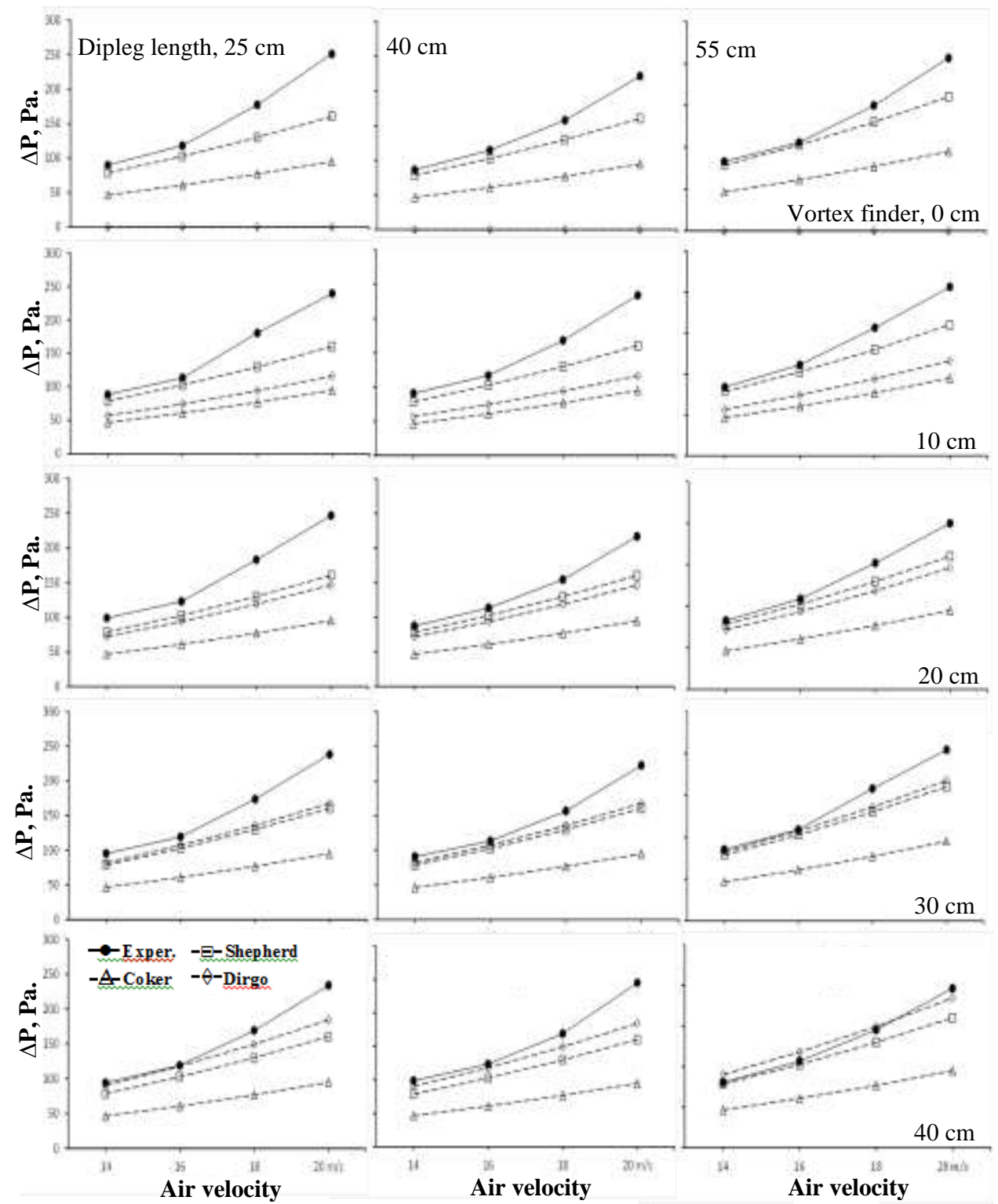

Fig. (6): The measured and predicted pressure drop at different coefficient models $\left(\xi_{\mathrm{c}}\right)$ under the cone height of $\mathbf{5 0}$ cm at different dipleg lengths and vortex finder lengths. 


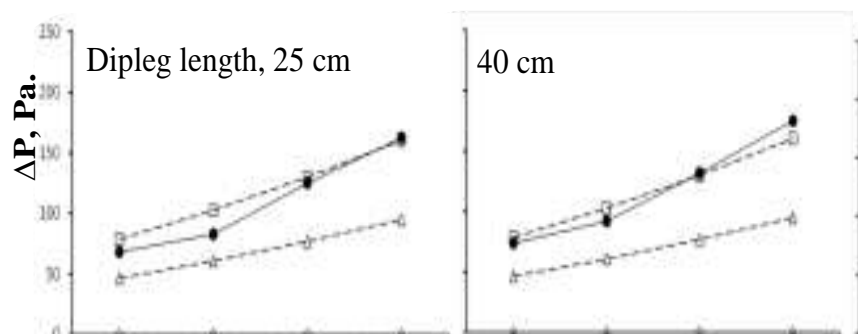

$55 \mathrm{~cm}$
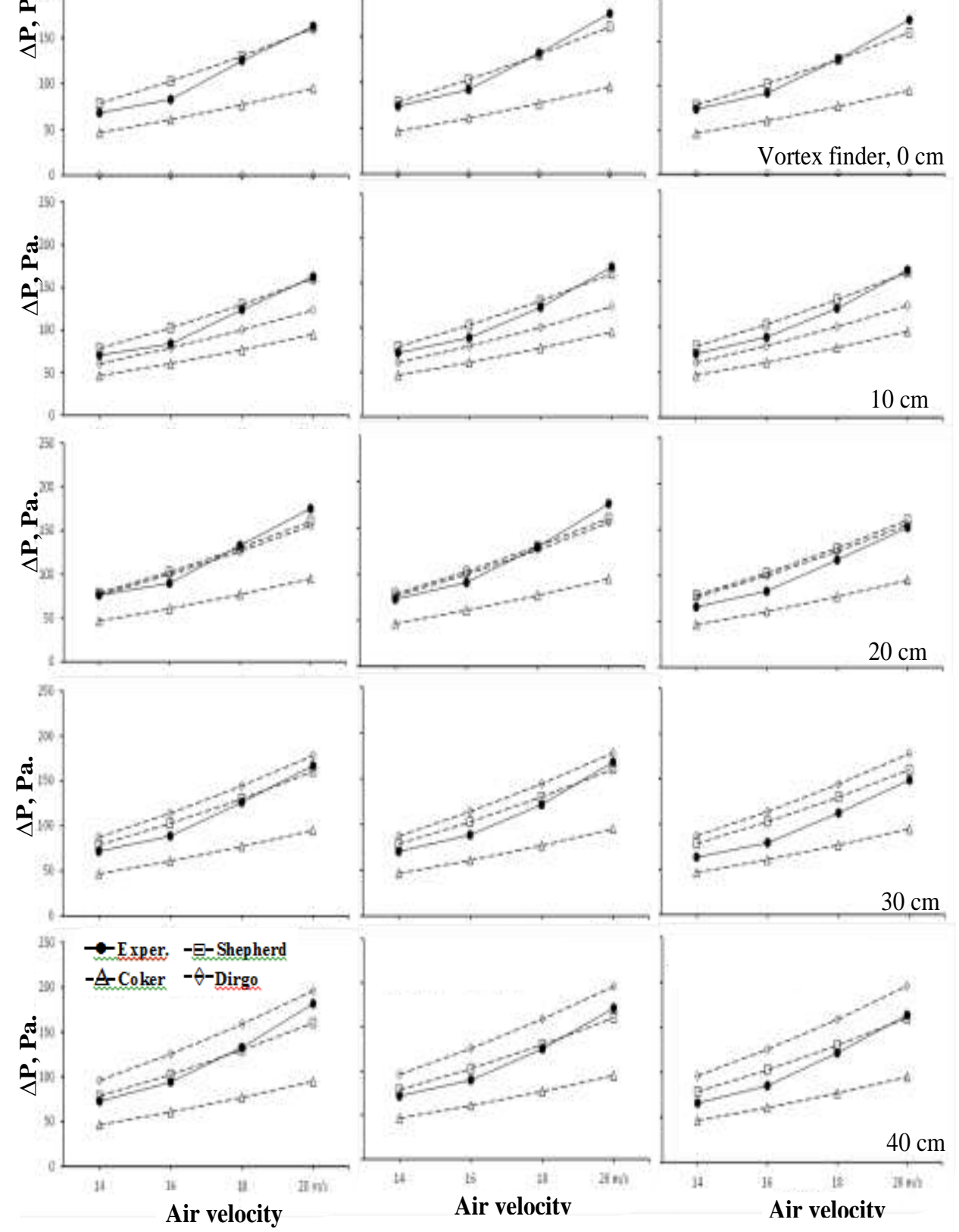

Fig. (7): The measured and predicted pressure drop at different coefficient models $\left(\xi_{c}\right)$ under the cone height of $70 \mathrm{~cm}$ at different dipleg lengths and vortex finder lengths. 
Table (5): Correlation between the best predicted pressure drop models and experimental results under different cone heights.

\begin{tabular}{|c|c|c|c|c|}
\hline \multirow{2}{*}{$\begin{array}{l}\text { Validation } \\
\text { parameters }\end{array}$} & \multirow{2}{*}{ Models } & \multicolumn{3}{|c|}{ Cone height, $\mathrm{cm}$} \\
\hline & & 30 & 50 & 70 \\
\hline \multirow{3}{*}{$\mathbf{R}$} & Shepherd \& Lapple & 0.97807 & 0.98023 & 0.96987 \\
\hline & Coker & 0.97807 & 0.98023 & 0.96987 \\
\hline & Dirgo & 0.48309 & 0.39186 & 0.41430 \\
\hline \multirow{3}{*}{ MRD, \% } & Shepherd \& Lapple & 18.8 & 9.9 & 17.5 \\
\hline & Coker & 29.7 & 36.5 & 51.1 \\
\hline & Dirgo & 43.8 & 35.4 & 36.9 \\
\hline \multirow{3}{*}{ RSEP, \% } & Shepherd \& Lapple & 16.8 & 9.3 & 24.6 \\
\hline & Coker & 32.9 & 39.9 & 54.6 \\
\hline & Dirgo & 51.9 & 48.9 & 52.2 \\
\hline \multirow{3}{*}{ RMSE } & Shepherd \& Lapple & 17.9 & 11.1 & 38.6 \\
\hline & Coker & 35.1 & 47.4 & 85.8 \\
\hline & Dirgo & 55.2 & 58.2 & 81.9 \\
\hline
\end{tabular}

Table (6) displaied the correlation between the Shepherd \& Lapple model and experimental results under the best validation cone height of $50 \mathrm{~cm}$ as aforementioned at different dipleg lengths. The Shepherd \& Lapple model was more validation to experimental data at dipleg lengths of 40, 25 and $55 \mathrm{~cm}$, respectively, due to the high value of (r) and lowest value of (MRD, \%), (RSEP, \%) and (RMSE) respectively. In other word, the Shepherd \& Lapple model was the best predicted model of $\Delta \mathrm{P}$ especially under cone height of $50 \mathrm{~cm}$ and dipleg length of $40 \mathrm{~cm}$.

Table (6): Correlation between the Shepherd \& Lapple model and experimental results under different dipleg lengths at cone height $50 \mathrm{~cm}$.

\begin{tabular}{llll}
\hline \hline \multirow{2}{*}{$\begin{array}{l}\text { Validation } \\
\text { parameters }\end{array}$} & \multicolumn{3}{c}{ Dipleg length, cm } \\
\cline { 2 - 4 } & $\mathbf{2 5}$ & $\mathbf{4 0}$ & $\mathbf{5 5}$ \\
\hline \hline $\mathbf{R}$ & 0.98284 & 0.98870 & 0.97879 \\
MRD, \% & 8.8 & 8.4 & 12.4 \\
RSEP, \% & 8.8 & 8.0 & 11.1 \\
RMSE & 10.6 & 9.7 & 12.7 \\
\hline \hline
\end{tabular}

As observed from Table (5) the Dirgo model was less value of (r) and highest value of (MRD, \%), (RSEP, \%) and (RMSE), but Figures (5, 6 and 7) display that, the vortex finder length effect on $\Delta \mathrm{P}$ in Dirgo model, 
where $\Delta \mathrm{P}$ was increased with increase vortex finder length. Thus to determine the best correlation of Dirgo model under the vortex finder length the statistics values were focused in Table (7).

Table (7): Correlation between the predicted pressure drop of Dirgo model and experimental results under different vortex finder lengths.

\begin{tabular}{llllll}
\hline \hline \multirow{2}{*}{$\begin{array}{l}\text { Validation } \\
\text { parameters }\end{array}$} & 0 & $\mathbf{1 0}$ & $\mathbf{2 0}$ & $\mathbf{3 0}$ & $\mathbf{4 0}$ \\
\cline { 2 - 6 } & - & 0.00085 & 0.00094 & 0.00094 & 0.00090 \\
\hline \hline $\mathbf{r}$ & 100.0 & 20.8 & 17.9 & 25.2 & 31.2 \\
MRD, \% & 100.0 & 34.3 & 23.2 & 24.6 & 29.2 \\
RSEP, \% & 128.9 & 43.8 & 30.2 & 31.5 & 38.1 \\
RMSE &
\end{tabular}

Table (7) illustrated that, The Dirgo model was more validation to experimental data at vortex finder lengths of 20,30 and $10 \mathrm{~cm}$, respectively, due to it has the high value of (r) and lowest value of (MRD, $\%),(\mathrm{RSEP}, \%)$ and (RMSE), respectively. While the vortex finder 40 and zero cm were lowest validation to Dirgo model.

\section{CONCLUSIONS}

- The obtained results inducted that, the experimental pressure drop increased with increase inlet air velocity and cone height.

- The maximum $\Delta \mathrm{P}$ were $161.3,181.7$ and $250.8 \mathrm{~Pa}$ recorded at inlet air velocity of $20 \mathrm{~m} / \mathrm{s}$, cone heights of 30,50 and $70 \mathrm{~cm}$ under vortex finder lengths of 40, 40 and $0 \mathrm{~cm}$ and dipleg lengths of 55, 25 and 25 $\mathrm{cm}$, respectively. Meanwhile, the minimum $\Delta \mathrm{P}$ were $60.2,63,6$ and $80.6 \mathrm{~Pa}$ recorded at inlet air velocity of $14 \mathrm{~m} / \mathrm{s}$, cone heights of 30,50 and $70 \mathrm{~cm}$ under vortex finder lengths of 10,30 and $40 \mathrm{~cm}$ and dipleg lengths of 25,55 and $55 \mathrm{~cm}$, respectively.

- The observed results showed that, the effect of both vortex finder length and dipleg length on $\Delta \mathrm{P}$ was tiny effect and neglected.

- The Barth and Casal \& Martinez-Benet models were given an extreme result comparing with measured pressure drop.

- The best model to predict the pressure drop was Shepherd \& Lapple, Coker and Dirgo, respectively. The Shepherd \& Lapple model has 
the highest value of (r) 0.86260 and lowest value of MRD, RSEP \% and RMSE which are 15.4, 19.6 and 25.4, respectively.

- Shepherd \& Lapple model was more validation comparing with other models. In the same time, the model was more validation with cone heights of 50, 30 and $70 \mathrm{~cm}$, respectively. Meanwhile, the predicted model Coker was more validation with cone heights of 30,50 and 70 $\mathrm{cm}$, respectively.

- Dirgo model was more validation to experimental data at vortex finder length of $20 \mathrm{~cm}$ then 30 and $10 \mathrm{~cm}$, respectively.

\section{REFERENCES}

Abdel-Hadi, M. A. (2014): Effect of cyclone inlet velocity and vortex finder height on coarse wheat bran dust separation. Misr J. Ag. Eng., 31(3): 1001-1024.

Azadi M.; M. Azadi and A. Mohebbi (2010): A CFD study of the effect of cyclone size on its performance parameters. Journal of Hazardous Materials, 182(1-3): 835-841.

Barth, W. (1956): Design and layout of the cyclone separator on the basis of new investigations. Brennstow-Wäerme-Kraft (BWK), 8(4): 1-9. Germany.

Casal, J. and J. M. Martinez-Benet (1983): A better way to calculate cyclone pressure drop. Chemical Engineering, 90(2): 99-100.

Chen, C. C. and R. V. Morey (1989): Comparison of four EMC/ERH equations. Trans. Amer. Soc. Agr. Eng., 32: 983-989.

Chen, J. and M. Shi (2007): A universal model to calculate cyclone pressure drop. Powder Technology, (171): 184-191.

Chuah, T. G.; J. Gimbun and T. S. Y. Choong (2006): A CFD study of the effect of cone dimensions on sampling aerocyclones performance and hydrodynamics. Powder Technology, 162: 126132.

Chuah, T. G.; J. Gimbun; T. S. Y. Choong and A. Fakhru'l-razi (2003): Numerical prediction of cyclone pressure drop. Journal of Chemical Engineering and Environment, 2(2): 67-71.

Clifford, M.; R. Brooks; A. Howe; A. Kennedy; S. McWilliam; S. Pickering; P. Shayler and P. Shipway (2009): An introduction 
to Mechanical engineering, Part 1. ISBN: 9780340939956. PP:511.

Coker, A. K. (1993): Understand cyclone design. Chemical Engineering Progress, 28: 51-55.

Cortés, C. and A. Gil (2007): Modeling the gas and particle flow inside cyclone separators. Progress in Energy and Combustion Science, 33(5): 409-452.

Demir, S.; A. Karadeniz and M. Aksel (2016): Effects of cylindrical and conical heights on pressure and velocity fields in cyclones. Powder Technology, 295: 209-217.

Dewil, R.; J. Baeyens and B. Caerts (2008): CFB cyclones at high temperature: operational results and design assessment. Particuology, 6(3): 149-156.

Dirgo, J. (1988): Relationships between cyclone dimensions and performance. Ph.D. Thesis, Havarad University, USA.

Elsayed, K. (2011): Analysis and optimization of cyclone separators geometry using RANS and LES methodologies. Ph.D. Thesis, Department of Mechanical Engineering, Faculty of Engineering, Vrije University. Brussel, Belgium.

Faulkner, W. B. and B. W. Shaw (2006): Efficiency and pressure drop of cyclones across a range of inlet velocities. Applied Engineering in Agriculture, American Society of Agricultural and Biological Engineers ISSN 0883-8542, 22(1): 155-161.

Ghasemi, J. and A. Niazi (2005): Tow- and three- way chemometrics methods applied for spectrophotometric determination of lorazepam in pharmaceutical formulations and biological fluids. Analytic Chimica Acta, 533: 169-177.

Hoekstra, A. J. (2000): Gas flow field and collection efficiency of cyclone separators. Ph.D. Thesis, Technical University Delft. Netherland.

Hoffmann, A. C., and L. E. Stein, L. E. (2008): Gas cyclones and swirl tubes: principles, design and operation. ISBN 978-3-540-74694. $22^{\text {nd }}$ Edition, Springer Berlin Heidelberg, Germany. 
Hoffmann, A. C.; A. van Santen and R. W. K. Allen (1992): Effects of geometry and solid loading on the performance of gas cyclones. Powder Technol. 70: 83-91.

Jachner, S.; K. G. van den Boogaart and T. Petzoldt (2007): Statistical Methods for the Qualitative Assessment of Dynamic Models with Time Delay (R Package qualV). Journal of Statistical Software, 22(8): 1-30.

Juengcharoensukying, J.; K. Poochinda and B. Chalermsinsuwan (2017): Effects of Cyclone Vortex Finder and Inlet Angle on Solid Separation Using CFD Simulation. Energy Procedia, 138: 11161121.

Kanshio, S. (2015): Multiphase flow in pipe cyclonic separator. Ph.D. Thesis, Oil and Gas Engineering Centre, Cranfield University. UK.

Li, M. F; X. P. Tang; W. Wu and H. B. Liu (2013): General models for estimating daily global solar radiation for different solar radiation zones in mainland China. Energy Convers Manag., 70: 139-48.

Schnell, K. B. and C. A. Brown (2002): Cyclone design. Air pollution control technology, Chapter 21. Handbook, Edited by Frank, K., CRC Press LLC, Florida, USA.

Shepherd, C. B. and C. E. Lapple, C. E. (1939): Air Pollution Control: A Design Approach, In Cyclones. $2^{\text {nd }}$ Edition, Woveland Press Inc., Illinois, USA. Pp 127-139.

Spatz, C. (2008): Basic statistics: Tales of distributions. $9^{\text {th }}$ Edition, Belmont, CA: Thomson Wadsworth, ISBN- 10: 0-495-50218-9. USA.

Tantar, A. A.; E. Tantar; P. Bouvry; P. Del Moral; P. Legrand; C. A. C. Coello and O. Schütze (2014): EVOLVE-A Bridge between Probability, Set Oriented Numerics and Evolutionary Computation. Springer International Publishing Switzerland. eISBN 978-3-319-07494-8. PP: 414.

Van den Berg, C.; S. Bruin; In L. B. Rockland and F. Stewart (1981): Water activity :influences on food quality. New York: Academic Press, Pp: 147-177. USA. 


\section{الملخص العربي \\ تأثير العوامل التصميمية والتشغيلية على فرق الضغط المقاس والمتتبأ به داخل السيكلون

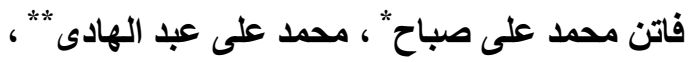

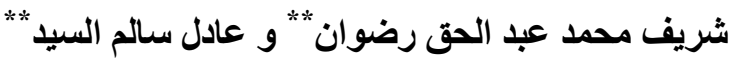

يعتبر السيكلون من أهم أجهزة تنقية الهو اء وفصل المواد الصلبة من تيار الهو اء و أكثر ها شيوعًا في العديد من الصناعات وعمليات ما بعد الحصاد. ويمتاز ببساطة التصنيع و التركيب و إنخفاض ونس اهن تكاليف الصيانة ويمكن تصنيعه من خامات بسيطة، و لا توجد به أجز اء متحركة، كما ان له القدرة على العمل في ظروف تشغيل صعبة مثل ارتفاع الضغط. و على الرغم من بساطة تركيبه، إلا أن

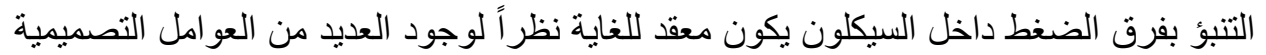
و التشغيلية المؤثرة على عملية التدفق وبالتالى فرق الضغط داخل السيكلون. و لا تز ال هنالك العديد من الدر اسات التجرييية و النظرية حول السيكلون والتي تهدف إلى فهم وتوقع فرق الضغط (DP)

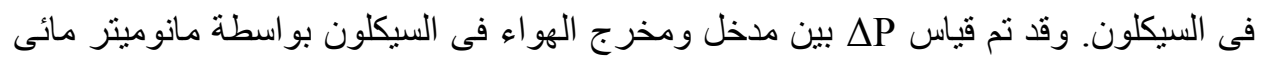

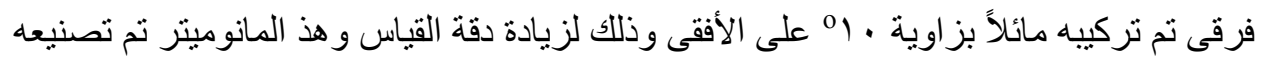

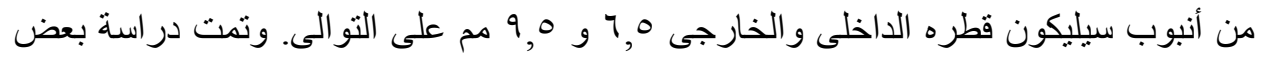

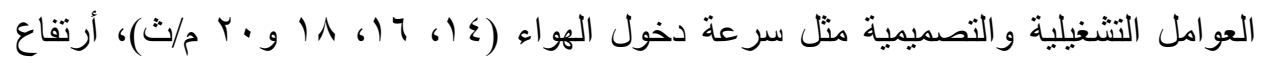

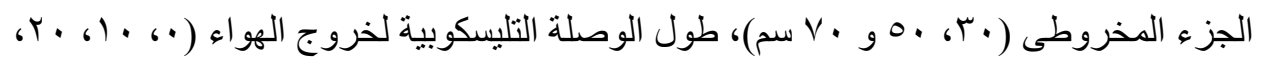

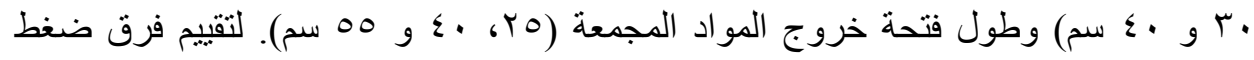

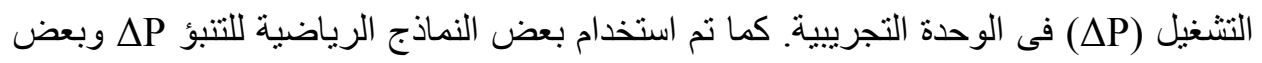
المقاييس الإحصائية للمقارنة و التحقق مع النتائج المقاسة.

\section{وقد توصلت الاراسة إلىى النتائج التالية: -}

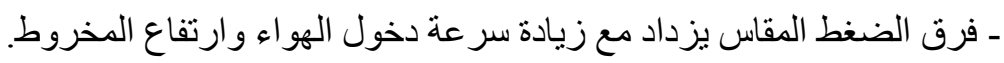

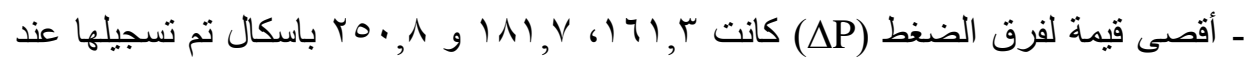

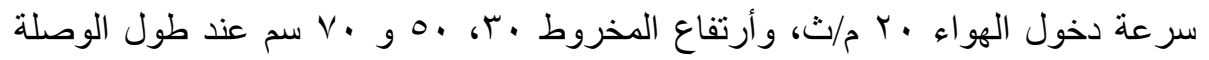

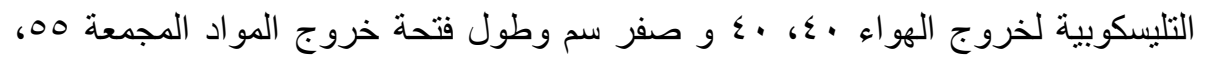

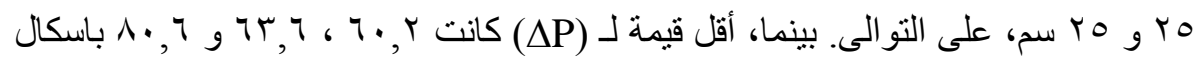

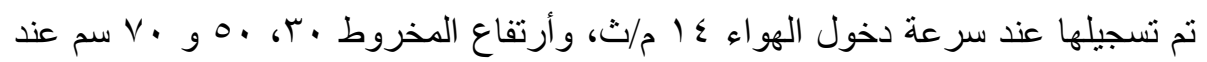

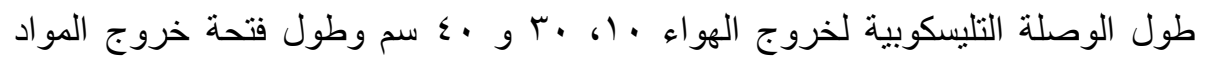

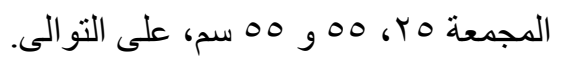

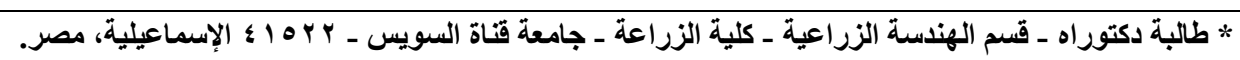
* * أستاذ الهندسة الزراعية ـ قسم الهندسة الزراعية ـ كلية الزراعة ـ جامعة قناة السويس. 
ـ كان تأثير كلاً من طول الوصلة التليسكوبية لخروج الهواء وطول فتحة خروج المو اد المجمعة

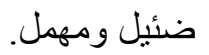
ـ أعطت نماذج Casal \& Martinez-Benet و نتائج متطرفة مقارنة بفرق

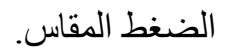

ـ أفضل نموذج للتنبؤ بفرق الضغط داخل السيكلون هو نموذج Shepherd \& Lapple

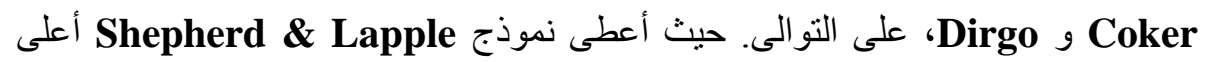

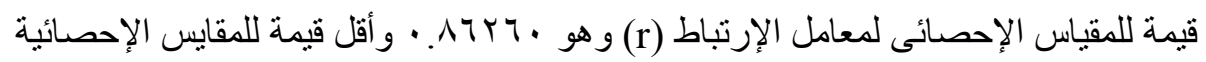
الاخرى (MRD, \%) ، (RSEP, \%) و (RMSE) و التى كانت 15.4 ، 19.6 و 25.4 على التو الىى.

ـ نموذج Shepherd \& Lapple هو أكثر النماذج تحقيقاً للتنبؤ بفرق الضغط داخل السيكلون

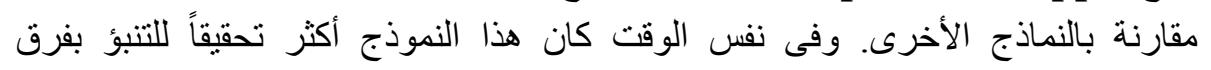

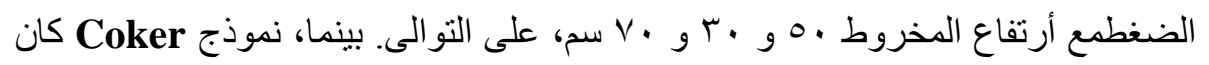

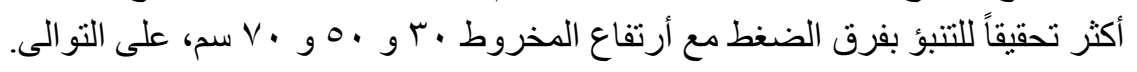

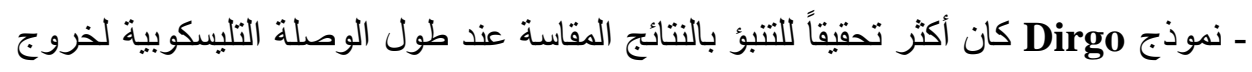

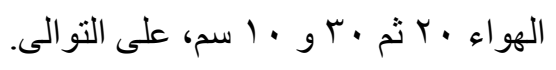

